\title{
Methodology of Forming a Comprehensive Mechanism for Public Administration of Service Cooperation Development in Rural Areas of Ukraine
}

\author{
Sergii Prylipko, Oleksandra Vasylieva, Nataliia Vasylieva
}

\begin{abstract}
: with carrying out the decentralization reform public administration mechanisms play an important role in ensuring the comprehensive development of rural areas. Expanding the use of such mechanisms in the sphere of cooperation on the state level will facilitate development and support of small entrepreneurial forms, common use of material and technical basis, emerging new working places, building social infrastructure and engineering communications, providing qualitative services to citizens and preserving rural settlements. The objective of the article is to identify constituents of the comprehensive mechanism of public administration for development of service cooperation of rural areas in Ukraine and to integrate them into a coherent system which would facilitate realization of the state strategies and programmes to achieve the Sustainable Development Goals. The object of the research is a comprehensive mechanism of public administration for development of service cooperation. Research methodology is grounded upon the use of general scientific knowledge methods, in particular, logical and semantic, induction and deduction for formulating definitions, systemic and situational analysis for characterizing constituents of a comprehensive mechanism and identifying their interrelations. Based on the systemic approach it has been defined that comprehensive mechanism is an integrated system which combines interrelated and dependable functioning of legislative, institutional, organisational and economic, financial and credit, information and communication as well as staffing mechanisms in the sphere of developing cooperative movement in the rural localities. It is proved that every mechanism influences its particular direction and is formed at the international, national, regional and local levels based on cooperative values and generalized system of principles. Special attention is paid to the research of international and national legislation to generalize the system of principles of cooperation, intermunicipal cooperation, public authorities and public associations' functioning, upon which the comprehensive mechanism for public administration of service cooperation development in rural areas of Ukraine is based.
\end{abstract}

Revised Manuscript Received on November 15, 2019

* Correspondence Author

Sergii Prylipko, Ph.D. in Economics, Associate Professor, Department of Public Administration and Public Service, National Academy for Public Administration under the President of Ukraine, Kyiv, Ukraine ORCID 0000-0002-6116-328X agroadvice@ukr.net

Oleksandra Vasylieva, Doctor of Science in Public Administration, Professor, Department of Public Administration and Public Service, National Academy for Public Administration under the President of Ukraine, Kyiv, Ukraine ORCID 0000-0003-1812-4557 sandra_nadu@ukr.net

Nataliia Vasylieva, Doctor of Science in Public Administration, Associate Professor, Department of Regional Administration, Local Self-Government and Urban Management National Academy for Public Administration under the President of Ukraine, Kyiv, Ukraine ORCID 0000-0003-4678-4333

vasilyeva.nadu@gmail.com
Keywords: public administration, comprehensive mechanism, cooperation, rural areas, cooperation principles, cooperative values, sustainable development, integrated approach.

\section{INTRODUCTION}

The agrarian sector reform initiated in 90-ties of XX century has not created the proper conditions for establishing high effectiveness indicators for small agricultural entrepreneurs and quality of life in communities. The comprehensive approach to public administration mechanisms functioning in rural areas still has misbalances and lack of integrity. Low effectiveness of small manufacturers of goods, low employment rate, poor communal and social infrastructure is resulted in gradual outflow of workforce. With increase of awareness on the provided by the decentralization reform possibilities for territorial communities to receive significant material, technical and financial resources for solving the most crucial problems of rural areas based on sustainable development, the cooperative movement is being widely spread among small businesses in the agrarian sector as well as residents of rural settlements. Proper use of public administration mechanisms for service cooperation development will promote the development and support of small entrepreneurial forms, common use of the material and technical base, emerging new jobs, constructing social infrastructure and utilities, and preserving rural settlements. There are mainly agricultural service cooperatives in Ukraine. They do not meet the needs of rural population in quality services provision. Therefore, the creation of service cooperatives in the spheres of housing, communal services, construction, transport, maintenance, information, tourist and recreation services etc. will solve the problems of integrated development of rural areas. For this purpose, it is necessary to form a comprehensive mechanism of public administration for the development of service cooperatives of rural areas in Ukraine. On the one hand, the functioning of such mechanism is to be aimed at developing an effective model of public management for sustainable development of rural areas. On the other hand, this mechanism should solve the challenges of the development of territorial communities through service cooperation growth. The formation of a comprehensive mechanism for proper public administration will intensify the activity of cooperatives in rural areas, which will contribute to sustainable development.

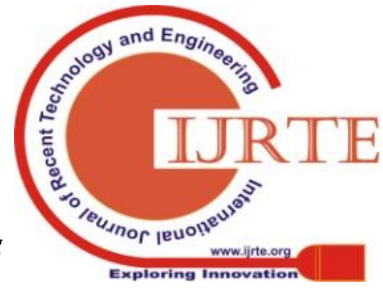




\section{Methodology of Forming A Comprehensive Mechanism for Public Administration of Service Cooperation Development in Rural Areas of Ukraine}

Local and regional government should focus on common European principles and standards: decentralization of public administration, deconcentration of power, partnership and cooperation among representatives of local executive bodies, local authorities, public associations and socially responsible business

\section{RESEARCH OBJECTIVE}

The objective of the article is to identify constituents of the comprehensive mechanism of public administration for development of service cooperation of rural areas in Ukraine and to integrate them into a coherent system which would facilitate realization of the state strategies and programmes to achieve the Sustainable Development Goals.

\section{DATA AND METHODS}

The methodology of forming a comprehensive mechanism includes a systemic approach to ensure interrelated functioning of legislative, institutional, organisational and economic, financial and credit, information and communication as well as staffing mechanisms taking into account cooperative values and a generalized system of principles of cooperation, the realization of which will be carried out with the help of cooperation actors.

The theoretical and methodological basis of the research was laid upon combination of general scientific and special methods, which helped identify the constituents of the comprehensive mechanism of public administration for development of service cooperatives of rural areas, reveal their content, establish interrelationship between them and construct an integral system of its functioning. The following methods were used: monographic - for carrying out scientific analysis of the research objective; logical and semantic, induction and deduction - for formulating definitions; analysis and synthesis, comparison and generalization - for characterizing constituents of an integrated mechanism for public administration and determining their interrelations for effective functioning.

The international and national legislation on cooperation, on public authorities and public associations' functioning, on intermunicipal cooperation became an information source for systematization and generalization of the principles system.

\section{RESULTS AND DISCUSSION}

Public administration for service cooperation development includes managerial decisions, taken jointly by public authorities, representatives of cooperatives and cooperation associations, business, civil society institutions and the international community. Such decisions will ensure development of a cooperative movement of services providers to agricultural producers and rural population on the basis of comprehensive approach to sustainable development of rural areas. All of the above actions are based on concrete interrelated mechanisms and tools of their implementation at the international, national, regional and local levels, using positive domestic and foreign experience.

In order to construct a comprehensive mechanism for public administration of service cooperation development in rural areas, it is foremost necessary to identify its structural elements, to characterize and determine their functional purpose, investigate the dependence and prove interrelations among them.

The legislative mechanism is aimed at creating favorable legal environment by forming and regulating legal relations between subjects and objects in order to provide comprehensive support to the service cooperatives development in rural areas at the national, regional and local levels. It is based on harmonized laws and regulations - state and regional strategies, concepts, target programmes, decrees, orders, directions, instructions, and other legislative institutional and departmental documents. It should be noted that the overwhelming majority of current state strategic documents include the achievement of Sustainable Development Goals.

The institutional mechanism operates on the basis of dependable links between institutional actors, represented by various international, governmental, local, public and other formal and informal institutions and organizations. Their activities are connected with promotion of cooperative movement development, coordination of activities for implementing the planned activities and tasks set out in the above-mentioned legislative documents.

Organizational and economic mechanism forms an effective organizational structure of vertical and horizontal cooperation among representatives of public authorities, public associations, private domestic and foreign investors, institutions and organizations with cooperative relations actors who foster the cooperation development in rural areas. As a result economically and legally grounded managerial decisions are taken based on the use of appropriate methods, tools and instruments. On the other hand, the organizational and economic mechanism of the direct activity of cooperative organizations includes constructing a strong organizational scheme of their cooperation, taking into account horizontal and vertical specificities, clustering and integration at the local, regional, national and international levels.

The financial and credit mechanism provides the use of various tools, instruments and incentives to meet the necessary needs of cooperative relations actors in the field of investing, lending, tax policy, customs tariff regulation, insurance, budgeting through the implementation of results-based programmes for service cooperatives development in rural areas, which are financed out of the state and local budgets. In the context of the decentralization reform, we believe that the use of the results-based method is the basis for the formation of local and regional programs for cooperation support. This would facilitate entrepreneurs and rural population to receive quality services and create comfortable living conditions in communities. Significant financial and credit resources require service cooperatives to create a proper material and technical base for the provision of housing, communal, construction, transport, maintenance, information, tourism and recreation services etc. in rural communities. Public-private partnership is one of the effective financial instruments for public authorities and cooperatives to implement results-based programs of comprehensive rural development.

The functional use of the information and communication mechanism is the systematic collection of the necessary analytical data at the national level with the help of specially developed software as well as the establishment of communication links in order to meet the needs of consumers in 
information services. At different levels of operational management, it is necessary to constantly monitor the effectiveness of legislation, the planning and use of budget funds, the implementation of state and regional programs. It is crucial to identify shortcomings, make proposals for change management and take the relevant managerial decisions. the information and consultation mechanism in a village, provide consultative support to cooperative actors, and become connectors among these actors, public authorities, public associations, business representatives and international grant projects.

The staffing mechanism includes functioning of the relevant system of training, retraining, advanced training and internship for state executive bodies, local governments, public associations and cooperative organizations in order to supply them with qualified personnel, whose activities relate to the cooperative relations development in rural areas. A modern manager must possess the appropriate combination of skills and professional qualities as well as qualification requirements of the position. With implementation of decentralization reform professional staff should have the profound knowledge of the legislative framework for comprehensive rural development and analytical thinking. While using integrated analysis a professional should be able to take economically grounded managerial decisions under the changing environment and innovations, should participate in developing strategic documents, manage projects, to establish good public relations based on modern information technologies, to demonstrate leadership skills, to organize and control tasks implementation, to establish social cooperation between stakeholders, etc.

It should be noted that the formation of a comprehensive mechanism of public administration for service cooperation development in rural areas stipulates that the legislative, institutional, organisational and economic, financial and credit, information and communication as well as staffing mechanisms, as well as its constituents should be interrelated and dependable. The basis for any managerial decision is the adoption of appropriate legislation, which is developed on the basis of economically grounded calculations. With existing legislative basis budget planning and implementation of the set activities in the frames of results-based programmes for service cooperatives development in rural communities are carried out. Responsible institutions coordinate mutual work. In the process of taking managerial decisions at all stages qualified personnel is involved. This example proves that all structural elements of the comprehensive mechanism are interrelated and interdependent Therefore, the effectiveness of reforms implementation in the sphere of service cooperatives development in rural areas will be efficient only under the condition of functioning its constituents, i.e. legislative, institutional, organizational and economic, financial and credit, information and communication, as well as staffing mechanisms, as an integrated system, but not as a separate component. We believe that the principles of forming these mechanisms should be based on standardized managerial approaches, methods and functions, with their elements being interconnected, capable to adapt rapidly under modern transformations within the state's agrarian policy.

Effective functioning of comprehensive mechanism of public administration can be fully realized on the basis of cooperative values and cooperation principles. Advisory bodies should act as an instrument for implementing

Cooperative values are the basis for forming a cooperative movement and integrate features of humanity and tolerance into activities of cooperatives. With their help people implement cooperative principles that are relatively mobile in the process of evolution, can not be "fossil" or eternal. Therefore, they need to be periodically rethought, reviewed, rebuilt and improved (Nosulich, Spyleva, 2013). Self-assistance, independence, democracy, equality, justice and solidarity were identified as the cooperative values at the Congress of the International Cooperative Alliance (ICA) in 1995. We consider them to be necessarily taken as a basis for forming the constituents of comprehensive mechanism.

Principles are always an integral part of the functioning of any mechanism. A principle is a generalized rule of an activity that ensures its correct implementation, but does not guarantee its uniqueness and success. It is a basic initial ground of any theory, doctrine, science, ideology; it is the internal conviction of a person, which determines its relation to reality, behavioral norms; it is the key specificity of any mechanism set-up (Vakulenko, Orlaty, Ignatenko, 2010).

We believe that the generalized system of principles for public administration of service cooperatives development is formed with the systemic combination of principles, namely (Tabl. 1.)

- cooperation principles which are defined in the Declaration of Cooperative Principles of ICA and in the Law of Ukraine "On Cooperation";

-principles of public authorities functions, which are reflected in the laws of Ukraine "On central executive bodies", "On local state administrations", "On local self-governance in Ukraine",

- principles of cooperation, defined in the laws of Ukraine "On the Cooperation of Territorial Communities" and "On Public-Private Partnership";

- principles public associations activities, which are specified in the Law of Ukraine "On Public Associations".

Therefore, we believe that the generalized system of public administration principles for service cooperatives development is formed with the help of systemic combination of cooperation principles, public authorities functioning principles, public associations functions principles.

Principles are a special system of ideas in the concept of cooperation. They are taken into account when drafting legislation on cooperative movement development in different countries. Their amendments allow adapting the activities of cooperatives to those changes that are constantly taking place in society (Vasylkivsky, Mirakin 2017). Cooperation principles have very specific historical and socio-economic background. They are subject to scientific analysis and continue to evolve in order to meet the growing needs. They reflect the specific social character of the cooperative form of management, and many of them are implemented to the extent of being consistent with economic appropriateness, competitiveness and viability of a cooperative. They should not be considered as a fixed notion. With the development of cooperative processes, such principles can be improved, specified and replenished with new meaning (Block, Goncharenko, Ivanova, 2001).

Separate mechanisms of public administration and their components form a coherent system. 


\section{Methodology of Forming A Comprehensive Mechanism for Public Administration of Service Cooperation Development in Rural Areas of Ukraine}

As its structural elements, they interconnect for implementing respective functions of the state through the use of a set of methods, tools and instruments of state influence. The comprehensive mechanism of public administration for sustainable development consists of the following mechanisms: legislative (includes a system of laws and regulations); institutional (a set of institutions, interconnections and coordination among them in order to achieve objectives and sustainable development goals); organizational-managerial (system of subjects and objects of the state regulation; aims, goals, functions and tasks of their activities; internal structure of their activities); financial and economic (financial and economic component of the regulatory mechanism; financial support for the regulatory process; combination of all economic methods, tools and instruments used for state regulation of sustainable development); information and communication (information support of the state regulation of sustainable development). To ensure the functioning of the comprehensive mechanism of state regulation, it is necessary to have the main objective of such regulation (in the global and national dimension as well as the general understanding), strategic goals, and further on - elaborating principles of functioning of the mechanism, in addition to which - subjects, objects, tasks, methods, forms of influence of state regulation of sustainable development (Buryk, 2017).

81 out of the 86 tasks $(94.0 \%)$ of 17 Sustainable Development Goals are partially or fully taken into account in the current state strategic documents of Ukraine: poverty reduction; zero hunger, developing agriculture; good health and well-being; quality education; gender equality; clean water and sanitation; affordable and clean energy; decent work and economic growth; industry, innovation and infrastructure; reduced inequality; sustainable cities and communities; responsible production and consumption; climate action; life below water; life on land; peace, justice and strong institutions; partnership for the goals. Most of them have a high and average integration level (from 75.0 to $100.0 \%$ ) in the state strategies and programmes. Therefore, the comprehensive mechanism of public administration for service cooperatives development in rural areas should be based on the awareness that, as a result of its functioning, it is expected that the state strategies and programs tasks aimed at achieving those Sustainable Development Goals, which are interrelated with the cooperation development in rural areas.

Taken into account the above, Fig. 1 presents the constituents of forming a comprehensive mechanism of public administration for the of service cooperatives development in rural areas of Ukraine.

Legend:

.$--- \quad$ integrated system;
$=====:$ Sustainable Development Goals which are
interrelated with cooperation development
The effectiveness and sustainability of the public
administration system depends on how flexible and adaptive
the links of institutions within the system of public
management interaction are. It also depends on the reaction of
this system to impulses which arise from the internal
environment (i.e. regulatory, institutional, functional,
socio-cultural impacts, scope of civil society development,

internal political, economic or managerial crisis) as well as from the complex of external factors (global economic crisis, external competition, globalization and integration processes) (Golub, 2015).

It should be noted that the functioning of all mechanisms in the comprehensive system should correlate with the set goals and objectives, their coherence and the interrelation among each other and with every separate structural element. Therefore, public administration actors should constantly monitor internal and external factors, timely identify problems, and take managerial decisions based on systemic approach, use scientific and special methods under the changing internal and external environment.

In the future the functioning of a comprehensive mechanism of public administration for the development of service cooperation in a coherent system will contribute to the sustainable development of rural areas in Ukraine.

\section{V.CONCLUSIONS}

Thus, on the basis of a systemic approach and use of a combination of scientific methods the constituents of a comprehensive mechanism of public administration for service cooperatives development in rural areas of Ukraine have been identified. The meaning and interrelation among every structural component has been defined and further united into a coherent system. As a result, this gives us the grounds to formulate a definition of "comprehensive mechanism of public administration for service cooperation development" which goes in line with the theory of public administration. This is an interdependent and coordinated system of functioning legislative, institutional, organizational and economic, financial and credit, information and communication, as well as staffing mechanisms in the sphere of cooperative movement development at the international, state, regional and local levels to ensure sustainable development, based on which an integrated system of cooperation principles and cooperative values is laid. At the same time, it should be noted that the integrated system of principles is formed due to systemic combination of cooperation principles, public authorities and public associations functioning principles.

\section{REFERENCES}

1. Bijman, J., Iliopoulos, C., Poppe, K. J., Gijselinckx, C., Hagedorn, K., Hanisch, M., ... van der Sangen, G. (2012). Support for Farmers Cooperatives : final report. Wageningen, The Netherlands: Wageningen UR.

2. Ramanauskas, J., Žukovskis, J., Zinivchuk V. (2017) Agricooperatives and producer's organizations: case of EU countries and lessons for Ukraine. Management Theory and Studies for rural Business and Infractructure Development. Vol. 39. \# 3, pp. 333-346.

3. Buendía, I. Côté, A. (2014) Territorial Rural Development and Cooperatives: an Analysis from Public Policies. Cuadernos de Desarrollo Rural, [S.1.], Vol. 11, N. 74 pp. 35-54.

4. Pejnović, D., Radeljak Kaufmann, P., Lukić, A., 2017: The influence of cooperatives on the regional and rural development of Croatia, Hrvatski geografski glasnik, 79 (2), 51-85.

5. Lugovyi, V.I. and Knyazev, V.M. (2004), Metodologhija derzhavnogho upravlinnja: slovnyk-dovidnyk [Methodology of public administration: dictionary-reference], NADU, Kyiv, 196 p. 
6. Sabluk, P. T. (2015) Rozvytok siljsjkykh terytorij v konteksti zabezpechennja ekonomichnoji stabiljnosti derzhavy [Development of rural areas in the context of providing economic stability of the state]. Materials of Ukrainian scientific-practical conferece "Socialjno-ekonomichni problemy rozvytku ukrajinsjkogho sela $i$ siljsjkykh terytorij" ["Socio-economic problems of development of Ukrainian villages and rural areas"]). Kyiv, Ukraine, pp. 4-18.

7. Kuybida, V.S., Bilynska, M.M., Petroe, A.M. (2018) Publichne upravlinnja: terminologhichnyj slovnyk [Public administration: terminology dictionary]). NADU, Kyiv, $224 \mathrm{p}$.

8. Latynin, M. A. (2007) Derzhavne reghuljuvannja rozvytku aghrarnogho sektora ekonomiky Ukrajiny [State regulation of the agrarian sector development of the economy of Ukraine: the dissertation's abstract]). Donetsk. 36 p.

9. Kuryltsiv, R., Kryshenyk N. (2018). The influence of rural development programmes on agricultural land use in Ukraine. Scientific Papers Series Management, Economic Engineering in Agriculture and Rural Development. Vol. 18/1, pp. 211-218.

10. Nosulich, T. M. and Spyleva, Ju. B. (2013) Kooperatyvna modelj socialjno-ekonomichnogho rozvytku Ukrajiny v suchasnykh umovakh [Cooperative model of social and economic development of Ukraine in modern conditions]) Economy. Management. Innovations, \# 2. URL: http://nbuv.gov.ua/UJRN/eui_2013_2_58

11. Vakulenko, V.V., Orlaty, M.K., Ignatenko, O.S. (2010) Zaghaljni zasady miscevogho samovrjaduvannja v Ukrajini [General Principles of Local Self-Government in Ukraine: textbook]. NADU, Kyiv, 400 p.

12. Vasylkivsky, D. M. and Mirakin, V. V. (2017) Sutj i pryncypy kooperatyvnykh form pidpryjemnycjkoji dijaljnosti [Essence and principles of cooperative business forms]. Bulletin of the Khmelnitsky National University. Economic Sciences. \# 6, vol. 2. pp. 7-10.

13. Block, R., Goncharenko, V., Ivanova, N. (2001) Siljsjkoghospodarsjki obslughovujuchi kooperatyvy [Agricultural Service Cooperatives] the practical guide). Kyiv, 288 p.

14. Buryk Z. M. (2017) Derzhavne reghuljuvannja stalogho rozvytku Ukrajiny: teorija ta praktyka [State regulation of sustainable development of Ukraine: theory and practice: monograph]. Lviv: Prostor-M Publishing House. 384 p.

15. Golub V. (2015) Efektyvna derzhava jak modelj suspiljnogho rozvytku [Effective state as a model of social development]. Materials of Ukrainian scientific-practical conferece "Aktualjni problemy derzhavnogho upravlinnja" [Actual problems of public administration]. Odessa, NADU, Vol. 2 (62). pp. 8-12.

\section{AUTHORS PROFILE}

Sergii Prylipko, Ph.D. in Economics, Associate Professor, Department of Public Administration and Public Service, National Academy for Public Administration under the President of Ukraine, Kyiv, Ukraine ORCID 0000-0002-6116-328X agroadvice@ukr.net

Oleksandra Vasylieva, Doctor of Science in Public Administration, Professor, Department of Public Administration and Public Service,

National Academy for Public Administration under the President of Ukraine, Kyiv, Ukraine ORCID 0000-0003-1812-4557

sandra_nadu@ukr.net

Nataliia Vasylieva, Doctor of Science in Public Administration, Associate Professor, Department of Regional Administration, Local Self-Government and Urban Management National Academy for Public Administration under the President of Ukraine, Kyiv, Ukraine ORCID 0000-0003-4678-4333

vasilyeva.nadu@gmail.com 